\title{
Incidence of spore-forming bacteria in unsweetened evaporated milk brands in Nigeria
}

\author{
Edema M.O* and Akingbade O.A \\ Department of Microbiology, University of Agriculture, Abeokuta, Nigeria \\ *Address for correspondence:- E-Mail: moedemao@yahoo.co.uk
}

ABSTRACT

\begin{abstract}
A total of forty-five samples of three most commonly consumed unsweetened evaporated milk brands purchased from retail outlets in South-western Nigeria were examined for occurrence of spore-forming bacteria. All the samples had high numbers of spore-forming bacteria of the genera Bacillus spp and Clostridium spp. with mean total aerobic viable counts of $2.15 \times 10^{5} \mathrm{cfuml}^{-1}$ for brand $\mathrm{A}$, $0.95 \times 10^{5} \mathrm{cfuml}^{-1}$ for brand $\mathrm{B}$ and $0.69 \times 10^{5} \mathrm{cfuml}^{-1}$ for brand C. Total anaerobic plate counts ranged from $0.13 \times 10^{5}$ for brand $\mathrm{C}$, to $0.54 \times 10^{5}$ for brand $\mathrm{B}$ and $1.67 \times 10^{5}$ for brand A. The organisms isolated from the three brands were identified as Bacillus cereus, Bacillus licheniformis, Bacillus coagulans, Bacillus stearothermophilus, Bacillus subtilis and Clostridium perfringens, with B. subtilis
\end{abstract}

having the highest frequency of occurrence $(93.33 \%)$. Samples were subjected to four different pasteurization treatments: $55^{\circ} \mathrm{C}$ for $30 \mathrm{~min}, 80^{\circ} \mathrm{C}$ for $15 \mathrm{~min}, 90^{\circ} \mathrm{C}$ for $10 \mathrm{~min}$ and $120^{\circ} \mathrm{C}$ for $30 \mathrm{sec}$, to determine a more efficient process. No growth was observed on culture plates of samples pasteurized at $120^{\circ} \mathrm{C}$ for $30 \mathrm{sec}$, except on aerobic plates of brand A. However the milk samples treated under this regime curdled. Samples pasteurized at $80^{\circ} \mathrm{C}$ for 15 min recorded the least counts next to samples treated at $120^{\circ} \mathrm{C}$ for $30 \mathrm{sec}$, without causing the samples to curdle.

Key Words: Evaporated milk, pasteurization, sporeforming bacteria, viable counts.

Federation defines pasteurization as a process applied to a product with the aim of avoiding public health hazards arising from pathogenic micro-organisms associated with such products by heat treatment which is consistent with minimal chemical, physical and organoleptic changes in the product (Kon, 1992). Milk is pasteurized by heating at a temperature of about $63^{\circ} \mathrm{C}\left(145^{\circ} \mathrm{F}\right)$ for $30 \mathrm{~min}$, rapidly cooling it, and then storing it at a temperature below $10^{\circ} \mathrm{C}$ $\left(50^{\circ} \mathrm{F}\right)$. Pasteurization kills most, but not all bacteria in milk. The combination of time and temperature used for heat treatment of milk are however, designed to kill all pathogenic microorganisms (ICMSF, 1998). In general thermoduric bacteria are most numerous. These bacteria which are heat resistant and usually survive pasteurization temperatures belong to the genera Bacillus, Clostridium, Mycobacterium, 
Micrococcus, Streptococcus and Lactobacillus. These organisms are therefore commonly found in milk when prevailing storage conditions permit their spores to germinate (for spore-formers), grow and eventually spoil the milk or pose health risk to consumers.

Milk is usually processed in a variety of ways. Condensed, evaporated, and powdered milk are produced by evaporating some or all of the water in milk with the intention of extending the shelf-life of the milk. The removal of about $50 \%$ water from whole milk results in the production of a light brown milk product called unsweetened evaporated milk. However with this amount of water, the milk is still susceptible to microbiological spoilage so the evaporated milk is packaged in cans and heat-processed under steam pressure in an attempt to destroy all the microorganisms present (Corlett and Denny, 1994).

The keeping quality of pasteurized milk depends both on the quality of heat treatment and on the extent of post - pasteurization contamination. This study was therefore aimed at evaluating the efficacy of the heat processing of three popular unsweetened evaporated milk brands sold in Nigeria by investigating the incidence of spore-forming bacteria in them.

\section{MATERIALS AND METHODS Collection of samples}

A total of forty-five samples of three popular brands of unsweetened evaporated milk consumed in south-western Nigeria were purchased from various outlets within the region and brought in ice buckets to the laboratory for analyses. Fifteen samples were collected per brand of evaporated milk.

\section{Microbiological analyses}

Samples were processed for analyses by the methods of Lyne \& Collins, 1990; Corlett and Denny, 1994). Ten-fold serial dilutions of milk samples were prepared and pour plating was done using $0.1 \mathrm{ml}$ portion each of appropriate sample dilution. Total viable counts were made on Plate Count Agar (PCA; Oxoid, Hampshire, UK) while thermoduric spore counts were determined by means of the laboratory pasteurization test (Harrigan and McCance, 1976). Isolation and enumeration of anaerobic spore-forming bacteria involved the use of Robertson's Cooked Meat Medium for spore germination and Reinforced Clostridial Medium for enumeration and isolation. Pour plating was on duplicate sets of plates each for Plate Count Agar (PCA) and Nutrient Agar (NA). Incubations were carried out at $37^{\circ} \mathrm{C} ; 7$ days for cooked meat medium and $37^{\circ} \mathrm{C} ; 3$ days for PCA and Nutrient Agar plates. One set of PCA and NA plates were incubated anaerobically in anaerobic jars using Oxoid gas generating kit while another set of plates was incubated at $30^{\circ} \mathrm{C} ; 3$ days to allow the growth of thermoduric bacteria. Poured plates without samples inoculated into them served as control. After incubation, suspected colonies were picked and identified on the bases of colonial, morphological and biochemical characteristics (Sneath et al, 1986).

Colonial characteristics included color of colonies, edges, appearance and elevation while morphological characteristics included gram staining (Claus, 1992), spore staining (Bartholomew and Mittwer, 1950) and motility test (Harrigan and McCance, 1976). Biochemical characterization involved patterns of sugar fermentation as well as utilization or production of specific nutrients or enzymes respectively. Classical microbiological analyses for identification were supplemented with biochemical typing using API $50 \mathrm{CHB} / 20 \mathrm{E}$ test kit (API Systems, Bio Merieux, France).

Pasteurization treatments: The pasteurization treatments employed in this work were $55^{\circ} \mathrm{C}$ for $30 \mathrm{~min}, 80^{\circ} \mathrm{C}$ for $15 \mathrm{~min}, 90^{\circ} \mathrm{C}$ for $10 \mathrm{~min}$ and 
$120^{\circ} \mathrm{C}$ for $30 \mathrm{secs}$. The samples subjected to these treatments were later examined microbiologically as earlier described for the numbers, if any, of spore-formers in order to determine and suggest the most appropriate pasteurization regime for the evaporated milk brands. Untreated samples of the same brand were used as control samples.

Data analysis: One-way ANOVA was performed to test for differences in spore-forming bacterial counts while bivariate correlations were carried out to determine the correlations among the factors investigated using SPSS 10.0 for Windows (SPSS Inc, Chicago, USA).

\section{RESULTS AND DISCUSSION}

Three commonly consumed unsweetened evaporated milk brands sold in various retail outlets in South-western Nigeria were examined for spore-forming bacterial contamination. Aerobic spore-forming bacterial counts showed that the samples contained an average of $2.15 \mathrm{x}$ $10^{5} \mathrm{cfuml}^{-1}$ for brand A, $0.94 \times 10^{5} \mathrm{cfuml}^{-1}$ for brand $\mathrm{B}$ and $0.69 \times 105$ cfuml $^{-1}$ for brand $\mathrm{C}$. Brand $\mathrm{A}$ also had the highest anaerobic bacterial counts of $1.67 \times 10^{5} \mathrm{cfuml}^{-1}$ while brand $\mathrm{C}$ had the least anaerobic bacterial counts of $0.13 \times 10^{5}$ cfuml $^{-1}$ (Table 1). There were no significant differences between aerobic and anaerobic plate counts of spore-forming bacteria among the three brands examined $(\mathrm{p}=0.05)$.

Out of the 150 randomly picked colonies developing on culture plates, eight species of both aerobic and anaerobic spore-forming bacteria were identified. They belonged to two genera Bacillus and Clostridium species. Aerobic endospore-forming bacteria were assigned to Bacillus species while anaerobic spore-formers were identified as Clostridium species. The percentage frequency of occurrence of the organisms is presented in Table 2. Bacillus subtilis was the most frequently isolated spore-former from all evaporated milk brands occurring in
93.33\% of all samples examined. It was followed by Bacillus stearothermophilus and $B$. licheniformis with $73.33 \%$ and $60.01 \%$ respectively. B. cereus (26.67\%) and Clostridium spp $(20 \%)$ showed the lowest frequency of occurrence in the milk samples examined. The effects of different pasteurization treatments on counts of both aerobic and anaerobic sporeforming bacteria are shown in Figs. 1 and 2 . Aerobic spore-forming bacterial counts of samples treated with pasteurization at $80^{\circ} \mathrm{C}$ for 15 min were between $0.03 \times 10^{5} \mathrm{cfuml}^{-1}$ for brand B to $0.04 \times 10^{5}$ cfuml $^{-1}$ for brands A and C. For samples subjected to pasteurization at $90^{\circ} \mathrm{C}$ for 10 mins, aerobic counts of spore-formers ranged from $0.13 \times 10^{5} \mathrm{cfuml}^{-1}$ for brand $\mathrm{C}$ to $0.52 \times 10^{5}$ cfuml $^{-1}$ for brand $\mathrm{A}$. For samples treated with high temperature of $120^{\circ} \mathrm{C}$ for $30 \mathrm{secs}$, no growth was observed on culture plates except for sample A with aerobic counts of $0.03 \times 10^{5} \mathrm{cfuml}^{-1}$. Samples treated with low temperature pasteurization of $55^{\circ} \mathrm{C}, 30 \mathrm{mins}$ had the highest counts of between $0.07 \times 10^{5} \mathrm{cfuml}^{-1}$ and 0.73 cfuml $^{-1}$ (aerobic); between 0.13 cfuml $^{-1}$ and 1.05 cfuml $^{-1}$ (anaerobic).

It was evident from the results obtained in the present study that spores of bacteria were present in all the milk samples examined. Similar species of aerobic and anaerobic spore-forming bacteria were isolated from the evaporated milk samples examined. This implies that primary contamination of the products may have occurred at the manufacturing sites. This is in agreement with a previous study, which showed that contamination at the factory could occur through the air in the holding tanks, pipes or the pasteurization room (Mahari and Gashe 1990). Contamination of milk products could also be incriminated to various roles performed by workers during milk processing (Gill et al, 1994). Eneroth et al.(2001) also reported contamination of pasteurized milk by Bacillus cereus during 
filling process at the dairy plants. The observation of higher counts of spore-forming bacteria in consumer packages compared to samples taken just before the filling machine was indicative of contamination of pasteurized milk in the filling machine.

The presence of bacterial spore-formers in evaporated milk samples observed in the present study indicates that their spores were able to survive the temperatures used for pasteurization of the milk samples to some extent. Spores of these organisms present in raw milk survive the heat treatment of pasteurization to later germinate and multiply in milk above $6^{\circ} \mathrm{C}$ (Griffiths, 1992). Bacillus spp are spore-forming organisms regarded as non-pathogens. Their presence may only serve as an indication of unhygienic standard of dairy products and may possibly reduce the shelf-life and quality of the products they contaminate (Gill et al, 1994). Dommett (1992) stated that the growth of psychrotropic sporeforming bacteria in milk limit the keeping quality of pasteurized milk. Viable counts were in the order of $10^{5}$ which placed the milk samples between acceptable and unsatisfactory bacteriological quality under the guidelines for the bacteriological quality of ready to eat foods (PHLS, 2000). Under the guidelines, aerobic colony counts must be less than 104 for the milk samples to be of satisfactory quality. This is significant from a food safety point of view, hence the need for further treatment and shelf life examination to assure the bacteriological quality of the milk samples. It is possible that the numbers of the spore-formers were within satisfactory limit at the time of production but increased along the distribution network because of the high atmospheric temperature which favored the germination of their spores.

Further pasteurization treatments reduced significantly $(\mathrm{p}<0.05)$ the numbers of sporeforming bacteria in the samples. This was probably due to the fact that the high holding temperature (i.e. ambient temperature of about $28 \pm 2$ in addition to the nutritionally rich milk medium permitted the germination of the spores into vegetative cells most of which do not survive high temperature pasteurization treatments.

The organisms isolated from evaporated milk brands in this work were identified as Bacillus cereus, Bacillus licheniformis, Bacillus coagulans, Bacillus stearothermophilus, Bacillus subtilis, Clostridium perfringens. Kalogridou-Vassiliadou (1992) isolated organisms similar to these from flat sour evaporated milk. He reported that the same strains produced various concentrations of acid in milk and concluded that these organisms may be responsible for the flat sour spoilage in evaporated milk. Hence the high numbers enumerated in this study could have implications for spoilage of evaporated milk. Spore-forming bacteria can survive food-processing treatments and in the dairy industry, Bacillus and Clostridium species determine the shelf-life of a variety of heat-treated milk products (Giffel, 2002).

Evaporated milk is made by removing half of the milk's moisture by evaporation before it is canned. Evaporated milk is sometimes used in cooking, both because it is easy to store and because it curdles less easily when heated than other milk. Unopened, it can be kept at room temperature for up to six months. However, the keeping quality of evaporated milk depends on the storage temperature which is relatively on the high side in a tropical climate as obtainable in Nigeria.

The findings of the present study have confirmed that pasteurization alone cannot get rid of all the bacteria in milk. Spores of some bacteria were found in the milk samples examined while further pasteurization did not totally eliminate spore-forming bacteria. 
Although numbers of spores in the treated samples were low, they could germinate into vegetative cells which could reach populations high enough to cause spoilage or constitute food safety risk within a few days. Dairy plants should ensure that adequate hygiene is observed during the preparation of the unsweetened evaporated milk in order to reduce the incidence of sporeforming bacteria in this important food material. Contaminations in storage tanks, pipe and from air source should be prevented. It is recommended that higher temperature should be applied in milk processing. Ultra-High Temperature (UHT) pasteurization, a relatively new technique used to sterilize foods for aseptic packaging is recommended for trial in the dairy industry. In UHT pasteurization, foods are heated to $138^{\circ} \mathrm{C}\left(280^{\circ} \mathrm{F}\right)$ for 2 to 4 secs allowing the food to retain more nutrients and better flavour.

Table 1: Total aerobic and anaerobic plate counts of spore-forming bacteria in samples of evaporated milk $\left(10^{5} \mathrm{cfu} / \mathrm{ml}\right)$

\begin{tabular}{lllll}
\hline Sample & TVC & TBC & ABC & NBC \\
\hline SA & $1.82_{\mathrm{c}}$ & $0.04_{\mathrm{b}}$ & $2.15_{\mathrm{c}}$ & $1.67_{\mathrm{c}}$ \\
Mean & $1.69-1.94$ & $0.01-0.06$ & $1.70-2.80$ & $1.50-1.90$ \\
Range & & & & \\
SB & $0.95_{\mathrm{b}}$ & $0.03_{\mathrm{a}}$ & $0.94_{\mathrm{b}}$ & $0.54_{\mathrm{b}}$ \\
Mean & $0.78-1.10$ & $0.01-0.07$ & $0.18-1.30$ & $0.30-0.80$ \\
Range & & & & \\
SC & $0.33_{\mathrm{a}}$ & $0.03_{\mathrm{a}}$ & $0.69_{\mathrm{a}}$ & $0.13_{\mathrm{a}}$ \\
Mean & $0.27-0.40$ & $0.01-0.05$ & $0.40-1.01$ & $0.07-0.20$ \\
Range & &
\end{tabular}

Key

Values are means of total number of samples examined

Values followed by different subscripts are significantly different by Duncan's multiple range test

TVC: Total viable counts $\quad T B C$ : Thermoduric bacterial counts

ABC: Aerobic plate counts $\quad N B C:$ Anaerobic plate counts

SA: $\quad$ Brand A

$S B: \quad$ Brand $B$

SC: $\quad$ Brand $C$ 
Table 2: Percent occurrence of isolated spore-forming bacteria in samples of evaporated milk

\begin{tabular}{llccc}
\hline Isolated bacteria & SA (\%) & SB (\%) & SC (\%) & Total (\%) \\
\hline Bacillus cereus & 20.00 & 6.67 & N.D & 26.67 \\
Bacillus licheniformis & 26.67 & 6.67 & 26.67 & 60.01 \\
Bacillus coagulans & N.D & N.D & 46.67 & 46.67 \\
Bacillus stearothermophilus & 40.00 & 33.33 & N.D & 73.33 \\
Bacillus subtilis & 60.00 & 20.00 & 13.33 & 93.33 \\
Clostridium perfringens & N.D & 6.67 & 13.33 & 20.00 \\
\hline
\end{tabular}

$\begin{array}{lll}\text { Key } & \text { SA: } & \text { Brand A } \quad \text { N.D: Not detected } \\ & \text { SB: } & \text { Brand } B \\ \text { SC: } & \text { Brand } C \\ & \text { Total number of samples }=15 \\ & \text { Percentages are calculated from number of samples containing the isolate. }\end{array}$

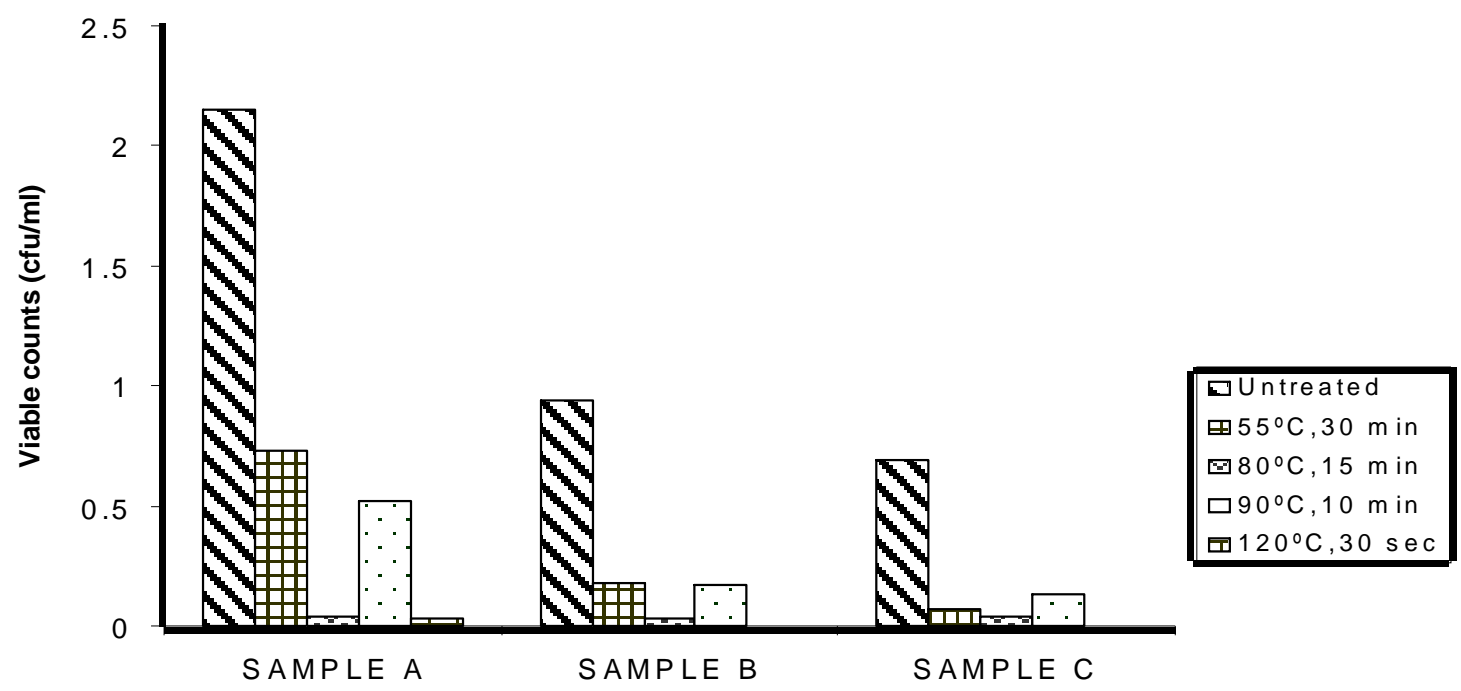

Fig 1. Effect of different pasteurization treaments on the total aerobic plate counts of spore formers in evaporated milk samples 


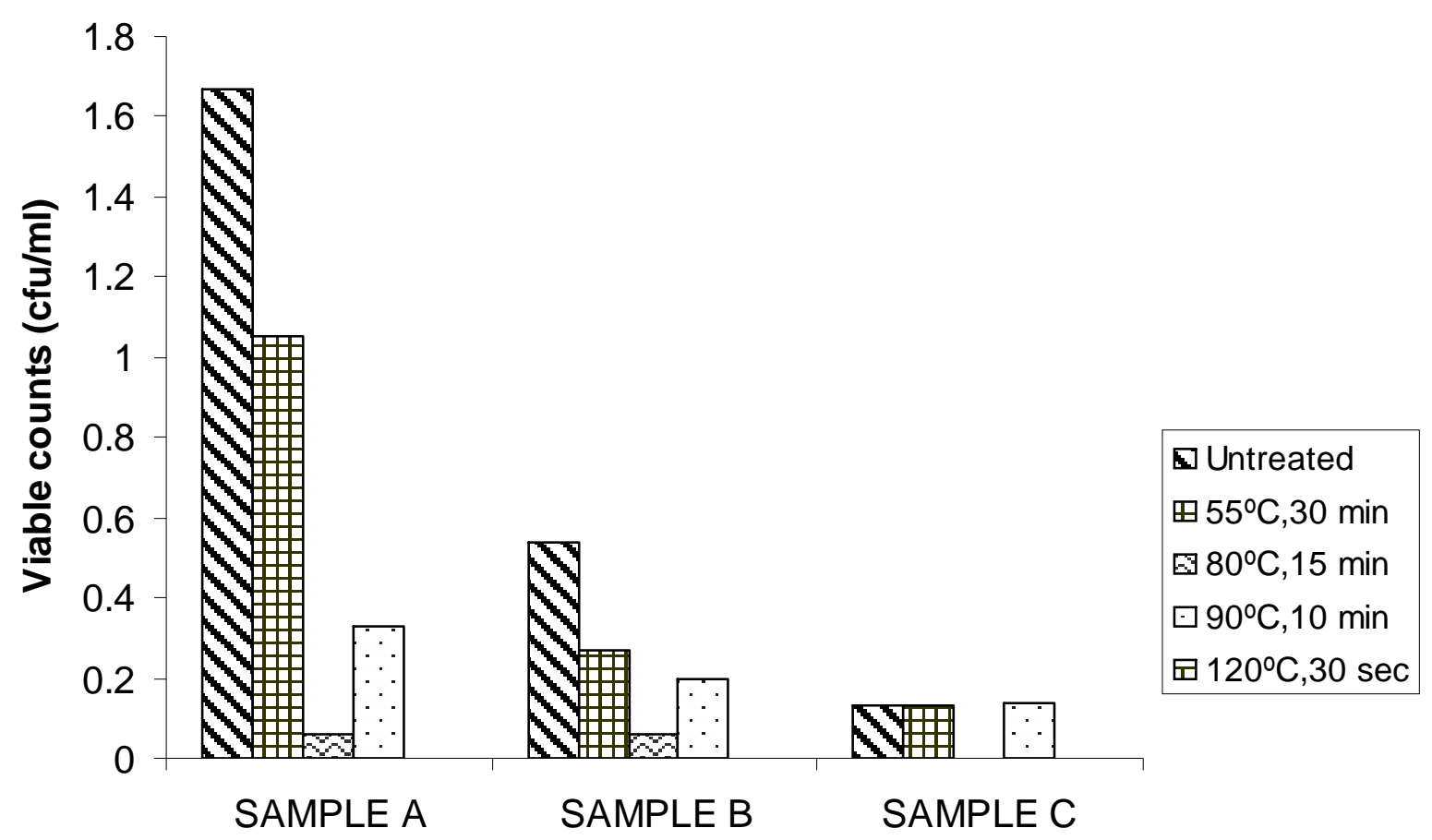

Fig 2. Effect of different pastenrization treatments on anaerobic plate counts of spore-forming bacteria in evaporated milk samples

\section{REFERENCES}

Bartholomew, J. W. and Mittwer D.C. (1950). A simplified bacterial spore stain. Stain Technology 25, 153.

Claus, D.C. (1992). A Standardized Gramstaining procedure. Wor. J. Microbiol. Biotechnol. 8, 451-452.

Corlett, D.A. and Denny, C.B. (1994). Canned foods test for cause of spoilage M.L Speck (ed.) In: Compendium of methods for the microbiological examination of foods 4 th A.P.H.A., Washington D.C. p 216-220 .
Dommett, T. W. (1992). Spoilage of aseptically pasteurized liquid dairy products by thermoduric psychrotrophs. Food Australia 44, 459-461.

Eneroth, A., Svensson, B., Molin, G. and Christiansson, A. (2001). Contamination of pasteurized milk by Bacillus cereus in the filling machine. $J$. Dairy Research 68, 189196.

Frazier, W. C. and Westhoff, D. C (1986). Food Microbiology. TMH Edt, New York. p. 540 . 
Giffel, M.C., Wagendorp, A., Herrewegh, A. and Driehuis, F. (2002). Bacterial spores in silage and raw milk Antonie van Leewenhoek 81, 625-630.

Gill, J. P. S, Joshi, D. V. and Kwatra, M. S (1994). Qualitative bacteriological survey of milk and milk products with special reference to Staphylococcus aureus. Indian Journal of Science 75, $51-55$.

Griffits, M. W. (1992). Bacillus cereus in liquid milk and other milk products. Bulletin of the Int'1 Dairy Federation 275: 36-39

Harrigan, W.F. and McCance, M.E. (1976) Laboratory methods in food and diary microbiology. Academic Press, London, U.K. p. 452 .

Henry, A and Newlander, I. (1997) Milk constituents In. Chemistry and Testing of diary products 5 th ed, John Wiley and Sons Inc, New York. p269-273.

ICMSF (International Commission on Microbiological Specification for Foods) (1998) Microorganisms in Foods. In Microbial ecology of food commodities. Academic Press New York, London. p522-532.

Kalogridou - Vassiliadou, D. (1992). Biochemical activities of Bacillus species isolated from flat sour evaporated milk. J. Dairy Sci. 75 (10) 2681-2686.
Kon, S.K. (1992) Milk and milk products In: Human Nutrition 3rd ed. FAO, Rome. p22-27. Lyne, P.M. and Collins, C. H. (1990). Microbiological methods 4th ed, Butterworth, London University press, Baltimore, p262264.

Mahari, T. and Gashe, B. A. (1990). A survey of the microflora of raw and pasteurized milk and the source of contamination in a milk processing plant in Addis Ababa, Ethiopia. Journal of Dairy Residence 57: 233 -235.

PHLS (2000). (Public Health Laboratory Service) Guidelines for the bacteriological quality of ready to eat foods sampled at the point of sale, Communication Disease and Public Health Vol.3, Number 3.

Sharma, D. K. and Joshi, D. V. (1992). Bacteriological quality of milk and milk products with special reference to Salmonella and its public health significance. Journal of Science and Technology 22: $100-103$

Sneath, P.H.A., Mair, N.S., Sharpe, M.E. and Holt, J.G. (1986). Bergey's Manual of Systematic Bacteriology Vol. 2. Williams and Wilkins Co. Baltimore, USA. 